Dla niektórych z nas, wytwórców kultury², idea stałej pracy to instytucja, której nawet nie bierzemy pod uwagę albo coś, na co decydujemy się tylko tymczasowo. Chcemy przecież czegoś innego. Czy nie chodziło nam zawsze o niebycie zmuszanym do oddawania się jednej czynności, jednej klasycznej definicji pracy, która ignoruje jej pozostałe

1 Lorey, Isabell. 2009. „Governmentality and Self-Precarization: On the Normalization of Cultural Producers." W Art and Contemporary Critical Practice: Reinventing Institutional Critique, red. Gerald Raunig i Gene Ray. London: MayFly. Licensed under Creative Commons Attribution-Noncommercial-No Derivative Works 3.0 Unported.

2 Używany w tym tekście desygnat „wytwórcy kultury” ma paradoksalny charakter. Odnosi się do wyobraźni stojących za nim podmiotów: na temat autonomicznego wytwarzania i modelowania samych siebie. Chodzi tu jednak również o to, że takie sposoby upodmiotowienia są narzędziami rządzenia, a zatem funkcjonalnymi efektami biopolitycznych społeczeństw urządzania powstałych w obszarze zachodniej nowoczesności. Termin „wytwórcy kultury” ma zatem sprzeczne znaczenia i nie dotyczy w pierwszej mierze artystów. Oferując taką konceptualizację, odnoszę się także do definicji autorstwa grupy kpD/kleines postfordistisches Drama (,mały postfordowski dramat”), do której należę wespół z Brigittą Kustner, Katją Reichard i Marion von Osten. „Stosujemy termin ”wytwórcy kultury» w strategiczny sposób. Używając go, nie mamy na uwadze jednego sektora (przemysł kultury) ani ustalonej kategorii społecznej (np. osób objętych systemem świadczeń społecznych dla artystów i pisarzy w Niemczech, który gwarantuje opiekę zdrowotną, emeryturę i ubezpieczenie od niebezpiecznych wypadków) czy definicji własnego zajęcia oferowanej przez określonych specjalistów. Mówimy w zamian o praktykach wędrowania w poprzek rozmaitych kwestii: teorii produkcji, designu, samoorganizacji politycznej i kulturowej, form współpracy, płatnej i niepłatnej pracy, nieformalnych i formalnych gospodarek, tymczasowych sojuszy, życia i pracy w modelu projektowym" (Kleines postfordistisches Drama 2005b, 24). 
aspekty; o niesprzedawanie się i niebycie zmuszanym do porzucania wielu aktywności, którymi chcemy się parać? Czyż nie było dla nas ważne nieprzystosowywanie się do ograniczeń instytucji, oszczędzanie czasu i energii, by podejmować się kreatywnych czy nawet politycznych projektów, które naprawdę nas interesują? Czy nie zdarzało nam się na chwilę przyjmować mniej lub bardziej dobrze płatne posady, by porzucać je w sprzyjających okolicznościach, gdy przestają nam już odpowiadać? Tak, by mieć trochę pieniędzy na czas kolejnego znaczącego projektu, który będzie prawdopodobnie mniej dochodowy, ale przypuszczalnie bardziej satysfakcjonujący.

Dla przedstawionej wyżej postawy kluczowe jest przekonanie, że możliwy jest wybór własnej sytuacji życiowej i zawodowej oraz że da się to zrobić w stosunkowo wolny i autonomiczny sposób. Sugeruje ona, co więcej, że nawet niewiadome czy brak ciągłości w określonych warunkach społecznych są tu do pewnego stopnia efektem świadomego wyboru. W kolejnych akapitach tego artykułu nie zajmuje mnie jednak pytanie „kiedy naprawdę decydowałam sama?” lub „kiedy działam autonomicznie?”, lecz kwestia konstytutywnego połączenia idei autonomii i wolności z hegemonicznymi sposobami upodmiotowienia w ramach zachodnich społeczeństw kapitalistycznych. Skupiam się tu na pytaniu, w jakim stopniu „świadomie wybrana” („self-chosen”) prekaryzacja przyczynia się do stworzenia warunków dla aktywnego uczestniczenia w neoliberalnych stosunkach politycznych i ekonomicznych.

Nie należy z tego ujęcia wyprowadzać żadnych ogólnych twierdzeń na temat wytwórców kultury czy tych osób, które znajdują się obecnie w prekarnej sytuacji. Gdy problematyzuje się kwestię „świadomie wybranej” prekaryzacji, widoczne stają się jednak historyczne linie sił (Foucault 2010b; Deleuze 2004) nowoczesnego upodmiotowienia burżuazji, które w niepostrzeżony sposób stają się hegemoniczne i normalizujące, dokonując prawdopodobnego zablokowania „kontrprowadzenia” (Foucault 2010, 210-213).

W celu przedstawienia genealogii owych linii zwrócę się najpierw w stronę pojęć „urządzania” i „biopolityki” w ujęciu Michela Foucaulta. Nie zamierzam się skupiać na zerwaniach czy załamaniach w obszarze burżuazyjnego upodmiotowienia. Interesować będzie mnie w zamian to, co w ich wypadku strukturalnie i transformacyjnie ciągłe, w tym techniki urządzania (governmental techniques) wykorzystywane dzisiaj w nowoczesnych społeczeństwach Zachodu. Jakie idee suwerenności wyłaniają się z owych nowoczesnych, rządowych urządzeń? Jakie linie sił - a zatem jakie ciągłości, oczywistości i normalizacje da się wyciągnąć z tego, co i jak myślimy, czujemy, traktując siebie jako „dobrowolnych” 
wytwórców kultury, którzy stali się prekarni w warunkach neoliberalizmu? Jak odnajdujemy się w szerszym świecie, a w szczególności jakie jest nasze miejsce w ramach tzw. praktyk oporu? Czy cierpiący prekarność wytwórcy kultury mogą ucieleśniać „nową” urządzeniową normalność w ramach określonych idei suwerenności i stosunku do samych siebie?

Odnosząc się do genealogii linii sił burżuazyjnego upodmiotowienia, dokonam w tym tekście rozróżnienia na prekaryzację jako dewiację, a zatem i sprzeczność na gruncie liberalnego urządzania, oraz prekaryzację jako hegemoniczną funkcję urządzania neoliberalnego. Wyjaśnię też zachodzącą między nimi relację na przykładzie „wolnej” decyzji dotyczącej prekarnego życia i pracy.

\section{Biopolityczne urządzanie}

Za pomocą pojęcia „urządzania” Michel Foucault definiuje strukturalny splot rządów Państwa oraz technik rządzenia sobą w społeczeństwach zachodnich. To wzajemne uwikłanie Państwa i populacji jako podmiotów nie jest ponadczasową stałą. Choć zaczęło się ono rozwijać w szesnastym wieku, jego prawdziwy początek przypada na wiek osiemnasty: pojawia się wtedy nowa technika rządzenia, czy mówiąc ściślej, linie sił nowoczesnych technik rządzenia, które funkcjonują aż do dziś. Tradycyjny suweren, którego prototyp Foucault dostrzega w postaci z Księcia Niccolo Machiavellego, oraz oparta na umowie dobrowolna wspólnota poddanych z siedemnastowiecznego traktatu Thomasa Hobbesa nie byli jeszcze zainteresowani sprawowaniem władzy nad „ludem” z myślą o jego dobrobycie. Chodziło im raczej o jego zdominowanie z uwagi na dobrobyt suwerena. Dopiero w osiemnastym wieku, gdy liberalizm i burżuazja zyskują pozycję hegemoniczną, populacja staje się przedmiotem zainteresowania władzy, a rządzenie zaczyna się skupiać na życiu „ludu” i tym, co czyni je lepszym. Władza Państwa nie zależy już jedynie od rozmiaru terytorium czy merkantylnego, autorytarnego regulowania działalności poddanych ${ }^{3}$, ale sprowadza się do zapewnienia „szczęścia” populacji, życia jej członków i stałej jego poprawy.

Z biegiem osiemnastego stulecia metody rządzenia przekształcały się w kierunku ekonomii politycznej liberalizmu: mamy wtedy do czynienia, z jednej strony, z ograniczeniami narzucanymi na siebie przez rząd $\mathrm{z}$ uwagi na korzyści wolnego rynku, z drugiej, z populacją podmiotów

3 Merkantylizm był również zorientowany na wzrost populacji, ale bardziej na poziomie aspektów ilościowych niż jakości życia „ludu”. 
związaną poprzez swoje poglądy i zachowania z paradygmatami ekonomicznymi. Podmioty te nie uległy podporządkowaniu poprzez proste środki posłuszeństwa, ale stały się podatne na rządzenie z uwagi na to, że „ich liczba, długość życia, zdrowie i sposoby zachowania splatają się z procesami ekonomicznymi” (Foucault 2011: 46). Liberalne sposoby rządzenia przedstawiały sobą podstawową strukturę dla nowoczesnego urządzania, które od zawsze było biopolityczne $e^{4}$. Innymi słowy, liberalizm stanowił ramę ekonomiczną i polityczną dla biopolityki oraz, w tym samym stopniu, był „niezbędnym elementem rozwoju kapitalizmu” (Foucault 2010b, 96).

Siła i bogactwo państwa pod koniec osiemnastego wieku zależały jeszcze mocniej od zdrowia jego ludności. W kontekście burżuazyjno-liberalnym zorientowana na takie kwestie polityka rządu aż do dzisiaj wiąże się z ustanawianiem, produkowaniem i zabezpieczaniem normalności. Potrzeba do tego znacznej ilości danych: wytwarzane są statystyki, oblicza się prawdopodobne wskaźniki narodzin i śmierci, częstotliwość chorób, warunków życia, zasobów żywieniowych itp. Jednak to nie wystarczy. W celu wytworzenia oraz maksymalizacji standardów zdrowej populacji owe bioproduktywne, wspierające życie metody rządzenia wymagają także aktywnej partycypacji każdej jednostki, a zatem rządzenia sobą. Jak pisał w Historii seksualności Foucault:

Człowiek Zachodu powoli dowiaduje się, co znaczy być żywym gatunkiem w żywym świecie, posiadać ciało, warunki egzystencji, widoki na przyszłość, zdrowie osobnicze i zbiorowe, siły zdatne do przekształcania i przestrzeń optymalnego ich użycia (Foucault 2010b, 98, podkreślenie I.L.).

Foucault opisuje tu, moim zdaniem, dwie kluczowe rzeczy: nowoczesna jednostka musi się uczyć tego, jak posiadać ciało zależne od określonych warunków egzystencjalnych oraz tego, w jaki sposób rozwijać kreatywny i produktywny związek z własnym ja, związek, w którym możliwe jest kształtowanie „własnego” ciała, „własnego” życia i „własnego” ja. Odnosząc się do zachodniego dyskursu higienicznego z końca osiemnastego i początku dziewiętnastego wieku, Philipp Sarasin wskazał na wyłaniające się wtedy „przekonanie, że jednostka jest w dużej mierze zdolna do określania stanu własnego zdrowia, choroby czy nawet czasu swojej śmierci (Sarasin 2001, 19). Owa idea zdolności do kształtowania własnego ja nigdy nie pojawia się niezależnie od urządzeń.

4 Foucault wskazuje na nierozdzielność nowoczesnego urządzania i biopolityki jedynie w kilku miejscach (Foucualt 2011, 49-50). W kwestii biopolitycznego urządzania jako pojęcia społeczno-teoretycznego zob. Lorey 2006 . 
W kontekście liberalnych technologii rządzenia „sobą” atrybut „własny” zawsze wskazuje na „posesywny indywidualizm” (Macpherson 1962). Początkowo stosunek do samego siebie zogniskowany na wyobrażeniu sobie tego, co dla mnie „własne” odnosił się tylko do burżuazji, jednak z czasem - pod koniec dziewiętnastego wieku - został on stopniowo rozciągnięty na całą populację. Na uwadze mamy tutaj nie prawny status podmiotu, lecz strukturalne warunki społeczeństw normalizacyjnych: należy w nich być zdolnym do zarządzania samym sobą, rozpoznania siebie jako podmiotu seksualności i uczenia się tego, jak posiadać ciało, które pozostaje zdrowe dzięki uważności (odżywianie, higiena, warunki życia) oraz może zachorować za sprawą nieuwagi. W tym sensie cała populacja musi składać się z podmiotów biopolitycznych (Lorey 2006a).

W odniesieniu do pracowników najemnych ów wyobrażony stosunek do siebie samego ${ }^{5}$ oznacza, że ciało, ustanawiane jako własność ja, staje się „własnym” ciałem, które należy sprzedać jako siłę roboczą. Idąc dalej tym tropem, nowoczesna, „wolna” jednostka jest zmuszona do współwytwarzania „ja” poprzez tak silny stosunek do samej siebie, że umożliwi on godziwą sprzedaż siły roboczej, pozwalając jej na stałą poprawę własnego życia.

W ten sposób w społeczeństwach nowoczesnych „sztuka rządzenia” - jak nazywał Foucault (2000) urządzanie - nie polega na byciu represyjnym, ale na „powodowanej wewnętrznie” samodyscyplinie i samokontroli'. To analiza porządku narzuconego ludziom, ciałom i rzeczom, które są jednak równocześnie jego aktywnymi częściami. W centrum problemu technik rządzenia nie znajduje się zatem kwestia regulowania autonomicznych, wolnych podmiotów, ale proces regulowania stosunków, poprzez które ustanawiane są w pierwszej mierze tzw. autonomiczne i wolne podmioty.

Już w drugiej połowie siedemnastego wieku John Locke, który, jak chce tego Marks, „wskazywał (...) że mieszczański rozsądek jest

5 Idąc tropem Louisa Althussera, zauważmy, że ów wyobrażony stosunek do samego siebie nie może być oddzielony od „warunków rzeczywistego istnienia”, czyli, w tym wypadku, urządzeniowych technik służących kontrolowaniu populacji, które mogą się materializować np. w konstytucji naszych ciał.

6 Zakładam, że przesunięcie zarządzania sobą „, do wewnątrz” i zastąpienie nim zasady regulacyjnej nie ma swoich początków w czasach neoliberalnych. Regulacja i kontrola nie są technikami ustanowionymi przez neoliberalizm, by przeciwstawić się dyscyplinie (Deleuze 2007; Hardt i Negri 2004). Jeśli technologie reprodukcyjne (wraz z higieną i dbałością o zdrowie) są przypisywane biopolitycznej produktywności ciał (które mają określoną płeć i rasę), to wprowadzenie tych praktyk upodmiotowienia zaczyna się dla burżuazji z początkiem ery nowoczesnej, przynajmniej pod koniec osiemnastego wieku. 
normalnym ludzkim rozsądkiem” (Marks, Engels 1966, 69), pisał w Dwóch traktatach o rządzie, że człowiek jest panem samego siebie, posiadaczem własnej osoby, jak również dysponentem swojej własności (Locke 1992). Wraz z początkiem epoki nowoczesnej własność zyskała „znaczenie antropologiczne" (Castel 2005, 24) tak dla przedstawiciela burżuazji jako warunek wstępny jego obywatelskiej wolności formalnej jak i robotnika, który posiadając swą siłę roboczą, musi ją sprzedać w sposób wolny - w zamian za płacę. Zakłada się tu, że wspomniany warunek wstępny umożliwia jednostce wybicie się na niezależność i wolność od tradycyjnego systemu podporządkowania i bezpieczeństwa. Jednak z perspektywy biopolitycznego urządzania znaczenie własności wyrasta ponad ograniczone poziomy obywatelstwa, kapitału i pracy najemnej, przyjmując w rzeczywistości całkowicie powszechną postać. W ramach biopolitycznego urządzania stosunki cielesnej własności odnoszą się bowiem do całej populacji, a nie jedynie obywateli czy robotników, na zasadach urządzeniowego rządzenia sobą ${ }^{7}$. Zgodnie z takim ujęciem nowoczesna osoba jest ustanowiona w ramach indywidualistycznych, posesywnych stosunków do samej siebie, które stanowią z kolei podstawę dla konkretnych, historycznych idei autonomii i wolności. Strukturalnie rzecz biorąc, nowoczesny stosunek do samego siebie opiera się (poza ekonomiczną interpelacja) na stosunku do własnego ciała jako środka produkcji.

W tak szerokim rozumieniu gospodarki i biopolityki zbiegające się ścieżki przedsiębiorczej pracy i „przedsiębiorcy samego siebie” (Pühl 2003) rozumiane jako sposoby upodmiotowienia sięgają swymi korzeniami do nowoczesnych społeczeństw liberalnych. Nie są zatem całkowicie neoliberalnymi zjawiskami ${ }^{8}$. Taka genealogia oczywiście pomija erę tego, co społeczne, czyli zainaugurowane z końcem dziewiętnastego

7 Inaczej rzecz ma się z biopolitycznym upodmiotowieniem, które różnicuje się z uwagi na gender, rasę, klasę, wyznanie religijne czy heteronormatywność. Nie mam tu niestety miejsca, by ową kwestię rozwinąć. Ogólnie rzecz biorąc, skupiam się tu na liniach sił upodmiotowienia burżuazji. Moim celem nie jest całościowe spojrzenie na sposoby konstytuowania się podmiotu.

8 W przeciwieństwie do tego twierdzenia Foucault (2011) pisze o tym zjawisku wyłącznie w połączeniu z formowaniem się neoliberalnego urządzania w Stanach Zjednoczonych, mając na uwadze osoby samozatrudnione. Podobnie wygląda to w badaniach opartych na jego tekstach (Bröcking 2000; Pieper i Gutiérrez Rodríguez 2003). Lemke $(2000,15)$ twierdzi, przykładowo, że gdy liberalna regulacja „wolności naturalnej” przekształciła się w „wolność sztuczną”, stało się możliwe wykrycie „przedsiębiorczego zachowania u racjonalnych ekonomicznie jednostek". W czym owa „wolność naturalna” różni się od urządzeniowych technik i walk społecznych? I czym miałoby być jej przeciwieństwo, „wolność sztuczna”? 
wieku czasy państwa dobrobytu, wiążąc kompulsywnie ustanawianych przedsiębiorców samych siebie w ramach obecnej rekonstrukcji i dekonstrukcji państwa socjalnego/dobrobytu z liberalnymi rządowymi metodami upodmiotowienia, zapoczątkowanymi pod koniec osiemnastego stulecia. To, co chyliło się ku upadkowi już sto lat później - prymat własności i związanych z nią form zabezpieczenia - zdaje się powtarzać dziś wraz z interpelacją wzywającą nas do wzięcia odpowiedzialności za samych siebie. Tak rozumianą własność wprowadzono na wczesnych etapach rządów burżuazji jako ochronę przed nieobliczalnością społecznej egzystencji oraz zabezpieczenie przed słabościami zsekularyzowanego społeczeństwa oraz dominacją książąt i królów. Odnosiło się to ostatecznie do ograniczonego kręgu ludzi, ale pod koniec dziewiętnastego wieku państwo narodowe musiało zagwarantować bezpieczeństwo społeczne dla wielu. Nie oznacza to jednak automatycznie, że dzisiejsze Państwo musi po raz kolejny podjać się kompleksowej społecznej funkcji zapewniania ochrony i bezpieczeństwa (Castel 2005). Wiązałoby się to raczej z szybką reprodukcją całkowicie elastycznego, charakterystycznego dla zachodniego państwa narodowego splotu wolności i bezpieczeństwa ze strukturalnymi włączeniami i wykluczeniami aniżeli zerwaniem z takim stanem rzeczy.

\section{Znormalizowane wolne podmioty}

W biopolitycznych, działających zgodnie z logiką urządzania społeczeństwach konstytuowanie tego, co „normalne” zawsze wiąże się z tym, co hegemoniczne 9 . Nowoczesne żądanie normalności - burżuazyjnej, heteroseksualnej, chrześcijańskiej, narodowej, białej i męskiej czy białej i kobiecej - prowadziło do rozwinięcia perspektywy kontrolowania własnego ciała i życia, regulowania i zarządzania ja. To, co normalne nie jest tożsame z normą, ale może pełnić tę samą funkcję. Normalność nie jest jednak nigdy czymś zewnętrznym, skoro to my sami okazujemy się jej gwarantami i reprodukujemy ją w kolejnych wariacjach. Idąc tym tropem, to my zarządzamy sobą w ramach urządzania, biopolityki i kapitalizmu, w których sami siebie normalizujemy. Jeśli proces ten jest skuteczny - a zazwyczaj jest - władza i określone stosunki dominacji

9 Foucault w swojej genealogii urządzania nie wskazuje na żadne wyraźne połączenia między tym, co normalne i tym, co hegemoniczne. W celu zrozumienia dynamiki i znaczenia urządzania należy badać mechanizmy normalizacji w bezpośrednim związku z produkcją dyskursów hegemonicznych i związanych z nimi walk. Na temat związków Foucaulta i Gramsciego zob. Hall 1997 i Demirovic 1997. 
są ledwie widzialne i niezwykle trudne do zrozumienia. Dzieje się tak, ponieważ współodpowiadamy za ich wytworzenie, odnosząc się do samych siebie i naszych własnych ciał. Społeczeństwo normalizacyjne i zachodzące na jego gruncie upodmiotowienie to historyczne efekty zorientowanej na życie technologii władzy. Podkreślmy raz jeszcze, że znormalizowany podmiot to historyczny konstrukt usytuowany w całokształcie (ensemble) form wiedzy, technologii i instytucji. Ów całokształt skupia się na indywidualnym ciele, jak również życiu całej populacji. Normalizacja jest z kolei przeżywana w ramach codziennych praktyk, które postrzegamy jako oczywiste i naturalne.

Co więcej, to, co normalne jest znaturalizowane jako efekt aktualności, autentyczności. Przykładowo, wierzymy, że skutkiem relacji władzy jest istota naszego ja, naszej prawdy, naszego własnego, właściwego jądra, źródła naszego bycia. Takie normalizujące rządzenie sobą opiera się na wyimaginowanej spójności, jednorodności i całości, które wiązać możemy z konstrukcją białego, męskiego podmiotu (Lorey 2006b). Koherencja okazuje się zatem ponownie warunkiem wstępnym nowoczesnej podmiotowości. Podmiot musi wierzyć, że jest on panem we własnym domu (Freud 2009). Jeśli takie wyobrażenie zawiedzie, dana osoba zaczyna uchodzić za „nienormalną” - tak w oczach innych, jak i we własnej opinii.

Pozostańmy przy wyuczonym sposobie odniesienia do samych siebie, które jest tak kluczowe dla nowoczesnej epoki biopolitycznego urządzania i dotyczy, na różne sposoby, całej populacji. Ów związek z samą sobą opiera się na idei posiadania wewnętrznej natury, istoty, która ostatecznie tworzy czyjąś unikalną indywidualność. Owe wyobrażone „wewnętrzne, naturalne prawdy”, konstrukcje aktualności uchodzą zazwyczaj za niezmienne, niepoddające się zniesieniu czy wyzwoleniu. Takie idee - o możliwości czy konieczności modelowania, projektowania własnego ja oraz wolnym, autonomicznym i samosterownym życiu - kwitną po dziś dzień. Stosunki władzy, o których mowa, nie są zatem łatwe do uchwycenia, kojarzymy je bowiem zwykle z czyjąś wolną decyzją, osobistym poglądem. Aż do dziś tworzą one pragnienia pytania: „kim jestem?” lub „jak zrealizować własny potencjał?”, „jak odnaleźć własne ja i w najlepszy sposób rozwinąć istotę mojego bycia?”. Jak pisałam wyżej, pojęcie odpowiedzialności za siebie samą, tak powszechnie wykorzystywane $\mathrm{w}$ ramach neoliberalnej restrukturyzacji, wpisuje się $\mathrm{w}$ linię posesywnego indywidualizmu i aktualności, ale funkcjonuje tylko $\mathrm{w}$ formie dodatku, jako neoliberalna interpelacja do rządzenia sobą.

Zasadniczo urządzeniowe rządzenie sobą wiąże się z widocznym paradoksem. Rządzenie, kontrolowanie, dyscyplinowanie i regulowanie za pomocą własnego ja jest równoczesne z modelowaniem i formowaniem 
owego ja, jego upodmiotawianiem, co oznacza czynienie go wolnym. Suwerennymi podmiotami można rządzić tylko w ramach takiego paradoksu. Właśnie dlatego, że techniki rządzenia sobą wyrastają z równoczesności podporządkowania i upodmiotowienia, kompulsji i wolności, jednostka w paradoksalnym ruchu staje się nie tylko podmiotem, ale jego specyficzną, nowoczesną $\mathrm{i}$ „wolną” odmianą. Tak upodmiotowiony podmiot uczestniczy ciągle w (re)produkowaniu warunków dla urządzania, stanowi bowiem podstawowy element w procesie wyłaniania się sprawczości. Zdaniem Foucaulta, władza jest sprawowana tylko nad „wolnymi podmiotami” i tylko w takim stopniu, w jakim są one „wolne” (Foucault 1998).

W kontekście urządzania podmioty są zatem ujarzmione, będąc zarazem aktywną częścią tego procesu i, w pewnym sensie, wolną osobą. Wolność, o której mowa, jest w tym samym czasie warunkiem i efektem liberalnych stosunków władzy, czyli biopolitycznego urządzania. Pomimo zachodzących w tej materii zmian, począwszy od końca osiemnastego stulecia, to jedna z linii sił, w której dochodzi do rządzenia jednostkami w społeczeństwach nowoczesnych.

Znormalizowana wolność w społeczeństwach biopolitycznego urządzania nie może się obyć bez mechanizmów bezpieczeństwa lub konstruktów tego, co nienormalne i dewiacyjne, które pełnią podobne, upodmiotawiające funkcje. Epoka nowoczesna nie da się bowiem pomyśleć bez imperatywu „niebezpiecznego życia” (Foucault 2010a, 478), bez permanentnej groźby normalnego, wyobrażonych inwazji stałych i powszechnych zagrożeń w rodzaju chorób, brudu, seksualności lub lęku przed zwyrodnieniem (Foucault 2010b) ${ }^{10}$. Wzajemne uwikłanie wolności i bezpieczeństwa, upodmiotowienia i kompulsji - nie bez udziału wspomnianego niebezpiecznego życia - napędza problemy ekonomii politycznej i władzy liberalnej.

Jeśli weźmiemy pod uwagę zarysowane wyżej tło, okaże się, że wszyscy ci, którzy nie stosują się do normy i normalizacji wolnego, suwerennego, burżuazyjnego, białego i męskiego podmiotu, jak również charakterystycznych dlań stosunków własności, stają się prekarni. Co więcej, w kontekście państwa socjalnego, które miało gwarantować bezpieczeństwo

10 Biopolityczne urządzanie w specyficzny sposób strukturyzuje społeczeństwa nowoczesne. W zwięzły sposób ujęła to Cornelia Ott: „pozwala to ludziom na rozumienie siebie w kategoriach wyjątkowych "podmiotów«, a jednocześnie sprowadza ich wspólnie do miana amorficznej, zunifikowanej »masowej populacji« (...). W ten sposób drugą stroną tego zjawiska jest zawsze raczej "prawo do życia" niż jego wykluczenie lub anihilacja” (Ott 1997, 110). W kwestii związków biopolitycznego uspołecznienia i kolonializmu zob. Lorey 2006b. 
w świecie nowoczesnej niepewności, spotykało to nie tylko kobiety, które stawały się prekarnymi jako żony z uwagi na zorientowane na mężczyzn normalne warunki pracy. Sytuację tę dzielili z nimi inni wykluczeni nienormalni i obcy - którzy nie pasowali do kompromisu kapitału i pracy ustanowionego na gruncie państwa narodowego (Kleines Postfordistisches Drama 2005a, 2005b; Mecheril 2003). Zgodnie z powyższym prekaryzacja tworzyła zawsze wewnętrzną sprzeczność liberalnego urządzania i jako coś nienormalnego naruszała stabilizującą dynamikę wolności i bezpieczeństwa. Stanowiła w tym sensie element uruchamiający kontrprowadzenie.

Obecnie normalne warunki pracy zorientowane na męskiego żywiciela rodziny, sytuacja, na którą pozwolić mogli sobie tylko przedstawiciele społecznej większości, tracą swą hegemoniczną pozycję. Prekaryzacja stanowi w coraz większym stopniu część urządzeniowych technik normalizacyjnych, co prowadzi do charakterystycznego przejścia w dobie neoliberalizmu - od wewnętrznej sprzeczności do funkcji hegemonicznej.

\section{Ekonomizacja życia i nieobecność kontrprowadzenia}

Dyskurs „ekonomizacji życia” uruchomił w ostatnich latach dyskusję, która nie dostarczyła satysfakcjonujących wyjaśnień dla neoliberalnych procesów transformacyjnych. Stało się tak nie tylko z racji jego totalizującej retoryki, ale i z powodu towarzyszącego jej obwieszczenia nadejścia rzekomo nowego zjawiska. „Ekonomizacja życia” odnosi się zazwyczaj do kilku uproszczonych tez: już nie tylko praca, ale także życie podlega interesom ekonomicznego wyzysku; nie jest już możliwe oddzielenie pracy i czasu wolnego, za czym idzie rozsadzenie rozróżnienia na produkcję i reprodukcję. Tak totalizujące tezy o zachodzącej na naszych oczach implozji podkreślają kwestię kolektywnej ofiary, wypaczając problematykę sposobów upodmiotowienia, sprawczości i kontrprowadzenia.

Teza „ekonomizacji życia” ma jednak sens w perspektywie biopolitycznego urządzania. Wskazuje bowiem na władzę i stosunki dominacji burżuazyjnego społeczeństwa liberalnego, które od przeszło dwustu lat organizuje się wokół produktywności życia. W omawianej perspektywie życie nigdy nie stanowiło drugiej strony pracy. W zachodniej nowoczesności reprodukcja to zawsze część tego, co polityczne i tego, co ekonomiczne. Nigdy nie znajduje się poza stosunkami władzy. To samo dotyczy ogólnie rozumianego życia. To ostatnie właśnie w jego produktywności (która oznacza jego potencjał projektowy) jest zawsze efektem takich stosunków. 
Wspomniany potencjał jest $\mathrm{z}$ kolei istotną składową domniemanego paradoksu zachodniego upodmiotowienia - stosunku podporządkowania i wzmocnienia ja, regulacji i wolności. Liberalny proces prekaryzacji jako wewnętrznej sprzeczności nie sytuuje się poza owym upodmiotowieniem, jest jej zupełnie prawdopodobnym rezultatem - wiązką pozycji społecznych, ekonomicznych i politycznych.

Opłakiwana dziś „ekonomizacja życia” nie jest w tym sensie całkowicie neoliberalnym zjawiskiem, lecz raczej linią sił społeczeństw biopolitycznych, którą udaje się dziś na nowo zrozumieć. Towarzyszące jej upodmiotowienia nie są tak nowe, jak zwykle się o nich twierdzi. Biopolityczne urządzeniowe ciągłości są jednak rzeczywiście trudne do uchwycenia.

Czy warunki życia i pracy, które nastały w kontekście ruchów społecznych drugiej połowy dwudziestego wieku, naprawdę nie mają nic wspólnego z urządzaniem ${ }^{11}$ Rzeczywiście, całkowicie dysydenckie praktyki związane z alternatywnymi sposobami życia, pragnienie innych ciał i stosunków do samych siebie (w kontekstach feministycznym, ekologicznym i radykalnie lewicowym) uporczywie dążyły do odróżnienia ich od normalnych warunków pracy i towarzyszących im ograniczeń, miar dyscyplinarnych i metod kontroli. Słowa kluczowe to w tym wypadku: decydowanie o tym, gdzie pracuję i z kim to robię oraz świadomy wybór prekarnych form pracy i życia, ponieważ zdolność do samodzielnego organizowania czasu i, co istotniejsze, samookreślenia oferują potencjalnie więcej wolności i autonomii. Zwykle w grę nie wchodzi tu dobra płaca, tak jakby wynagrodzeniem była sama radość płynąca z pracy. Idzie raczej o możliwość wykorzystania swoich umiejętności. Ogólnie rzecz biorąc, świadoma, dobrowolna akceptacja prekarnych warunków życia była często wyrazem nadziei na innego rodzaju nowoczesne doświadczenie niż to związane z normalną sytuacją pracowniczą i patriarchalnym rozdziałem na reprodukcję i pracę najemną.

To jednak właśnie te alternatywne warunki życia i pracy stawały się w ostatnich latach coraz bardziej użyteczne dla ekonomii, ponieważ faworyzowały one elastyczność, której domaga się rynek pracy. Tym samym praktyki i dyskursy ruchów społecznych w ostatnich trzydziestu,

11 Boltanski i Chiapello (2001) przyjmują, że chodzi tu, przeciwnie, o przywłaszczenie. Według prowadzonych przez nich badań zmiany w kapitalizmie, do których dochodzi od lat sześćdziesiątych dwudziestego wieku, mają swoje zakorzenienie w specyficznej integracji i strategicznym przeformułowaniu „krytyki artystycznej”, krytyki, która lamentuje nad jednorodnością społeczeństwa masowego, brakiem indywidualnej autonomii i utratą autentycznych relacji społecznych (zob. też Lemke 2004, 176-178). 
czterdziestu latach były nie tylko dysydenckie i skierowane przeciwko normalizacji, ale równocześnie przyczyniały się do transformacji w kierunku neoliberalnej formy urządzania.

Do jakiego jednak stopnia prekarne modele życia i pracy, które uznawano kiedyś za opozycyjne, stały się oczywiste w zakresie hegemonicznej, urządzeniowej funkcji? Dlaczego zdają się tracić swój kontrprowadzeniowy potencjał? Poniżej przedstawię kilka prób rozwiązania tych problemów, nie roszcząc sobie prawa do ukazania żadnej spójnej analizy.

Wielu wytwórców kultury, którzy z własnej woli żyją w warunkach prekarności i o których mówimy tu jako o pewnej całości, odniosłoby się świadomie lub nie do historii wcześniejszych alternatywnych warunków istnienia (zazwyczaj nie będąc z nimi w żadnej bezpośredniej politycznej relacji). Są oni w mniejszym lub większym stopniu zaniepokojeni wejściem w obszar społecznego centrum, czyli miejsca reprodukcji tego, co normalne i hegemoniczne. Nie oznacza to jednak, że przeszłe alternatywne techniki życia i pracy staną się społecznie hegemoniczne. Jest raczej odwrotnie: masowa prekaryzacja warunków pracy narzucana jest wszystkim tym, którzy rezygnują z normalnych warunków, obiecując sobie, że wezmą odpowiedzialność za własną kreatywność i zaczną modelować swoje życie wedle własnych reguł. To w tej sytuacji widzą oni pożądane, rzekomo normalne warunki egzystencji. Nasz namysł nie dotyczy tu zatem osób prekaryzowanych na siłę, ale tych, które utrzymują, że jako wytwórcy kultury sami wybrali prekarne warunki życia i pracy (Kuster 2006; Panagiotidis 2005).

Zadziwia brak systematycznych empirycznych badań owego zjawiska $^{12}$. Wspólne cechy wytwórców kultury powinny się sprowadzać do dobrego czy nawet bardzo dobrego wykształcenia, podobnego wieku (25-45 lat), nieposiadania dzieci i tkwienia w bardziej lub mniej zamierzonej prekarnej sytuacji zatrudnienia. Szukają oni tymczasowej pracy, żyją z projektów i zleceń od kilku klientów naraz, wykonując jedne po drugich bez chorobowego, płatnych wakacji czy zasiłku dla bezrobotnych. Jako że pozbawieni są jakiejkolwiek pewności zatrudnienia, nie przysługuje im również niemal żadne zabezpieczenie społeczne. Iluzją jest też w ich wypadku czterdziestogodzinny tydzień pracy. Czasu pracy i czasu wolnego nie rozdziela żadna jasno wytyczona granica. Nie da się już oddzielić aktywności zawodowej od nie-pracy. Poza pracą opłacaną wytwórcy kultury akumulują ogromne ilości wiedzy, za którą się

12 Wstępne próby jego zrozumienia można znaleźć u Böhlera i Scheiffele (2005); w badaniach Anny i Mariny Rambach (2001) na temat prekarnych intelektualistek we Francji; w tezach Angeli McRobbie (2004) dotyczących funkcjonalności artystów z punktu widzenia nowej gospodarki; lub badaniach kpD (2005b). 
dodatkowo nie płaci, a która jest naturalnie przywoływana i wykorzystywana w kontekście pracy najemnej itd.

Nie ma tu mowy o obezwładniającej i totalizującej, zewnętrznej względem podmiotu „ekonomizacji życia”. Chodzi tu raczej o praktyki odwołujące się do pragnienia i związane z przystosowaniem. Takie warunki egzystencji są stale oczekiwane i współwytwarzane w ramach antycypującego posłuszeństwa. To, co dobrowolne - np. niepłatne lub słabo płatne prace w przemysłach kultury i nauki - jest zbyt często przyjmowane jako niezmienny fakt, w którego miejsce nie żąda się niczego innego. Akceptuje się zatem konieczność poszukiwania innego, mniej kreatywnego, prekarnego zajęcia w celu sfinansowania własnej twórczości kulturowej. Te narzucone i, równocześnie, wybrane sposoby finansowania własnej kreatywności nieustannie wspierają i reprodukują dokładnie te stosunki społeczne, które powodują cierpienie jednostki i których częścią chce ona być. Być może opisywani tu pracownicy kreatywni, owe dobrowolnie sprekaryzowane wytwórczynie kultury z taką łatwością poddają się wyzyskowi, ponieważ łączą trudne warunki życia i pracy z wiarą we własną wolność i autonomię; znoszą je, mając na uwadze swoje fantazje o samorealizacji. Dzięki temu są do tego stopnia podatne na wyzysk, że w kontekście neoliberalizmu Państwo przedstawia ich pracę jako modelową.

Sytuacja samoprekaryzacji łączy się z doświadczeniami lęku i utraty kontroli, poczuciem niepewności, które towarzyszy utracie pewników i społecznych gwarantów bezpieczeństwa, jak również ze strachem i doświadczeniem porażki, społecznego upadku i biedy. Z tych samych powodów tak trudne jest „odpuszczenie” czy odrzucenie hegemonicznych paradygmatów. Należy żyć odpowiednio szybko, w przeciwnym razie można zanotować upadek. Nie istnieje czas czystego relaksu czy regeneracji sił. Taki rodzaj reprodukcji po prostu nie ma swojego miejsca, co owocuje nieukojoną tęsknotą i ciągłym cierpieniem z powodu tego braku. Niezaspokojone pozostaje też pragnienie wytchnienia, które pozwoliłoby jednostce na „odnalezienie siebie”. Z tego powodu takich praktyk reprodukcyjnych trzeba się zwykle uczyć na nowo. Nie ma w nich teraz nic oczywistego i trzeba o nie z goryczą walczyć przeciwko samemu sobie i innym. Tęsknota za reprodukcją i regeneracją staje się dzięki temu skrajnie urynkowiona.

W konsekwencji prekarna staje się nie tylko sfera pracy i produkcji, ale także jej tzw. druga strona, strefa reprodukcji zwykle definiowana jako „życie”. Czy dochodzi tu zatem do nakładania się produkcji i reprodukcji? W wypadku wytwórców kultury odpowiedź brzmi „tak”. Pokazują nam oni tym samym, że w neoliberalnej formie indywidualizacji 
pewne elementy produkcji i reprodukcji są zdeponowane „w” podmiocie. Panagiotidis i Tsianos $(2004,19)$ piszą w związku z powyższym, że „stopniowe przezwyciężanie rozdziału produkcji i reprodukcji nie zachodzi w domu czy w miejscu pracy, ale raczej poprzez ucieleśnienie samej pracy: to refleksyjna droga prekaryzacji”. To, co zmaterializowane w ciałach, poza pracą, to bowiem zawsze również życie urządzeniowe, jako że biopolityczne, urządzeniowe stosunki władzy funkcjonują uparcie poprzez produkcję hegemonicznych, znormalizowanych ciał i stosunków do samego siebie.

W panujących dziś czasach prekarności i tego, co niematerialne, zindywidualizowanej pracy i „życia” funkcja reprodukcji stale się zmienia. Nie jest już eksternalizowana na innych, szczególnie kobiety. Indywidualna reprodukcja i seksualna reprodukcja (czyli produkcja życia) stają się dziś wyraźnie zindywidualizowane i przesuwają się częściowo w stronę samych podmiotów. Mam tu na uwadze regenerację poza pracą, a nawet poprzez pracę, ale często w oderwaniu od adekwatnie płatnej pracy najemnej. Regenerację, odnowę, kreowanie własnego ja, reprodukowanie siebie własnymi sumptem i na własny koszt. Samorealizacja staje się zadaniem reprodukcji dla ja. A praca ma być gwarantem tego procesu.

Przedstawiając „sprekaryzowanych” wytwórców kultury w całej ich heterogeniczności w tak jednolity sposób, można powiedzieć, że ich upodmiotowienie w dobie neoliberalnej jest pełne sprzeczności: mamy tu bowiem równocześnie do czynienia z prekaryzacją, która oznacza również fragmentację i nieciągłość, oraz z ciągłością suwerenności. Ciągłość nowoczesnej suwerenności uskutecznia się poprzez stylizowanie samorealizacji, autonomii i wolności, poprzez modelowanie i odpowiadanie za własne ja oraz powtarzanie idei aktualności. Wskazać można tu przykład (nadal) szeroko rozpowszechnionej idei nowoczesnego podmiotu artysty (mężczyzny), który czerpie swą twórczość z samego siebie, ponieważ spoczywa ona rzekomo w jego wnętrzu, czyli tam, gdzie zachodnia nowoczesność widziała również płeć, czyniąc z niej naturę czy istotę jednostki. Ogólnie rzecz biorąc, dla przedstawionych tu wytwórców kultury suwerenność zdaje się sprowadzać, w większości wypadków, do „wolnej” decyzji o prekaryzacji, czyli samoprekaryzacji. To właśnie z tego powodu tak trudno rozpoznać w strukturalnej prekaryzacji neoliberalne urządzeniowe zjawisko, które dotyka całego społeczeństwa i nie ma wiele wspólnego z wolną decyzją. Wytwórcy kultury pokazują zatem, do jakiego stopnia „świadomie wybrane” sposoby życia i warunki pracy, w które wpisują się ich własne idee autonomii i wolności, są zgodne z polityczno-ekonomiczną restrukturyzacją. Jak inaczej wytłumaczyć to, że badając warunki życia i pracy krytycznych wytwórców 
kultury, na pytanie o „dobre życie” nie otrzymujemy żadnej odpowiedzi? ${ }^{13}$ Gdy życie i praca nachodzą na siebie w coraz większym stopniu, oznacza to, jak stwierdził jeden z ankietowanych, że „praca przenika twoje życie”. Oczywiście niewiele idei „dobrego życia” przenika zwrotnie świat pracy, co mogłoby z kolei przekształcić go w coś kolektywnie odbieranego jako właśnie „dobre życie”. Brakuje tu ewidentnie kontrprowadzenia, które mogłoby wieść do lepszego, coraz bardziej wyzutego z funkcji urządzania życia.

Najwidoczniej wiara w prekaryzację jako liberalnie urządzeniowe stanowisko opozycyjne może być podtrzymywana dzięki sprzecznemu, rozpartemu między suwerennością i fragmentacją upodmiotowieniu. W ten jednak sposób przysłania się trwałe stosunki władzy i dominacji, a mechanizmy normalizacji staje się czymś tak naturalnym, jak oczywiste i autonomiczne decyzje podmiotu. Dokłada się do tego jeszcze totalizujący dyskurs „ekonomizacji życia”, który czyni niewidocznymi efekty hegemonii, walki i antagonizmy. Odmienne wyobrażenia na temat autonomii i wolności nie są odzwierciedlane w ramach urządzeniowych linii sił nowoczesnego upodmiotowienia, co blokuje pojawienie się zachowań, które mogłyby sprzeciwiać się hegemonicznej funkcji prekaryzacji w kontekście neoliberalnego urządzania.

Jaka jest cena owej normalizacji? Co funkcjonuje w neoliberalizmie jako nienormalne? A co jako dewiacyjne? Co da się w ten sposób ekonomicznie wyzyskiwać? Zamiast mesjanicznego oczekiwania na kontrprowadzenia i nowe podmiotowości, czego domagał się retorycznie Deleuze zapytując: „czy mutacje kapitalizmu nie znajdują nieoczekiwanego »naprzeciw» w powolnym wyłanianiu się nowej Sobości (Soi)

13 Przygotowując projekt filmu Kamera Läuft! (Akcja!, Zürich/Berlin 2004, 32 min.), grupa kpD przeprowadziła pod koniec 2003 roku piętnaście wywiadów z berlińskimi wytwórcami kultury (w tym z członkiniami owej grupy), „z którymi pracowałyśmy, tworząc wspólnie specyficzną formę praktyk politycznych w polu kultury lub których praca stanowiła dla nas odniesienie. (...) Nasze pytania opierały się na kwestionariuszu stworzonym przez Fronte della Gioventù Lavoratrice i Potere Operaio, wykorzystanym w 1967 roku w Mirafiori, „Fiat jest naszym Uniwersytetem«, który, poza innymi kwestiami, zapytywał także o idee »dobrego życia« i organizacji. (...) Mając na uwadze potencjalne upolitycznienie wytwórców kultury, byłyśmy również zainteresowane strategiami kolektywnej odmowy oraz związanymi z tym marzeniami o poprawie własnego życia, życia innych i, ostatecznie, zmianie społecznej. Jedyny wątek, jaki uobecnił się ogólnie we wszystkich wywiadach, dotyczył cierpienia z powodu braku ciągłości. (...) My również nie odnalazłyśmy w naszym horyzoncie intelektualnym prawie żadnych alternatywnych pomysłów na życie, które mogłyby w jasny sposób przeciwstawić się tym już istniejącym” (Kleines Postfordistisches Drama 2005b, 24; 2005a). 
jako ogniska oporu?" (Deleuze 2004, 144) ${ }^{14}$, sądzę, że musimy nadal pracować nad kwestiami genealogii prekaryzacji jako funkcji hegemonicznej, problemu ciągłości na gruncie burżuazyjnych urządzeniowych sposobów upodmiotowienia, także biorąc pod uwagę pojęcia autonomii i wolności, które zdają się nam rezerwuarem oporu.

Przetożyt Piotr Juskowiak

14 Skrajny przykład takiej idei mesjanicznej odnajdziemy współcześnie w zakończeniu Imperium Hardta i Negriego (2004), jak również, chociaż w innej i bardzo osłabionej postaci, u Foucaulta (1998) żądającego narodzin nowych podmiotowości. 


\section{Wykaz literatury}

Boltanski, Luc i Eve Chiapello. 2005. The New Spirit of Capitalism. Tłum. George Elliott. London: Verso.

Bröckling, Ulrich, Susanne Krasmann i Thomas Lemke (red.). 2000. Gouvernementalität der Gegenwart: Studien zur Ökonomisierung des Sozialen. Frankfurt/Main: Suhrkamp.

Böhmler, Daniela i Peter Scheiffele. 2005. „Überlebenskunst in einer Kultur der Selbstverwertung." W Gesellschaft mit beschränkter Haftung: Zumutungen und Leiden im deutschen Alltag, red. Franz Schultheis i Christina Schulz. Konstanz: UVK.

Castel, Robert. 2005. Die Stärkung des Sozialen: Leben im neuen Wohlfahrtsstaat. Hamburg: Hamburger Edition.

Deleuze, Gilles. 2004. Foucault. Tłum. Michał Herer. Wrocław: Wydawnictwo Naukowe Dolnośląskiej Szkoły Wyższej Edukacji TWP we Wrocławiu.

Deleuze, Gilles. 2007. „Postscriptum o społeczeństwach kontroli.” W Negocjacje: 1972-1990. Tłum. Michał Herer. Wrocław: Wydawnictwo Naukowe Dolnośląskiej Szkoły Wyższej Edukacji TWP we Wrocławiu.

Demirovic, Alex. 1997. Demokratie und Herrschaft: Aspekte kritischer Gesellschaftstheorie. Münster: Westfälisches Dampfboot.

Foucault, Michel. 1998. „Podmiot i władza.” Tłum. Jacek Zychowicz. Lewa noga 9.

Foucault, Michel. 2000. „Rządomyślność.” W Filozofia, historia, polityka: Wybór pism. Tłum. Damian Leszczyński i Lotar Rasiński. Warszawa: Wydawnictwo Naukowe PWN.

Foucault, Michel. 2010a. Bezpieczeństwo, terytorium, populacja. Tłum. Michał Herer. Warszawa: Wydawnictwo Naukowe PWN.

Foucault, Michel. 2010b. Historia seksualności. Tłum. Bogdan Banasiak, Tadeusz Komendant i Krzysztof Matuszewski. Gdańsk: słowo/obraz terytoria.

Foucault, Michel. 2011. Narodziny biopolityki. Tłum. Michał Herer. Warszawa: Wydawnictwo Naukowe PWN.

Freud, Sigmunt. 2009. Wyktady ze wstępu do psychoanalizy: Nowy cykl. Tłum. Robert Reszke. Warszawa: Wydawnictwo KR.

Hall, Stuart. 1997. „The Spectacle on the »Other»”. W Representation: Cultural Representations and Signifying Practices, red. Stuart Hall, London: Sage.

Hardt, Michael i Antonio Negri. 2005. Imperium. Tłum. Sergiusz Ślusarski i Adam Kołbaniuk. Warszawa: Wydawnictwo W.A.B. 
Kleines Postfordistisches Drama/kpD. 2005a. „Prekäre Subjektivierung: Interview." Malmoe 7.

Kleines Postfordistisches Drama/kpD. 2005b. „Prekarisierung von KulturproduzentInnen und das ausbleibende "gute Leben «." arranca! 32 (Summer).

Lemke, Thomas. 2004. „Räume der Regierung: Kunst und Kritik der Menschenführung." W Foucault und die Künste, red. Peter Gente. Frankfurt/Main: Suhrkamp.

Lemke, Thomas, Susanne Krasmann i Ulrich Bröckling. 2000. „Gouvernementalität, Neoliberalismus und Selbsttechnologien.” W Gouvernementalität der Gegenwart: Studien zur Ökonomisierung des Sozialen, red. Ulrich Bröckling, Susanne Krasmann i Thomas Lemke. Frankfurt/ Main: Suhrkamp.

Locke, John. 1992. Dwa traktaty o rzadzie. Tłum. Zbigniew Rau. Warszawa: Wydawnictwo Naukowe PWN.

Kuster, Brigitta. 2006. „Die eigenwillige Freiwilligkeit der Prekarisierung.” Grundrisse, Zeitschrift für linke Theorie \& Debatte 18.

Lorey, Isabell. 2006a. „Als das Leben in die Politik eintrat: Die biopolitisch gouvernementale Moderne, Foucault und Agamben.” W Empire und die biopolitische Wende, red. Marianne Pieper, Thomas Atzert, Serhat Karakayali i Vassilis Tsianos. Frankfurt/Main: Campus.

Lorey, Isabell. 2006b. „Der weiße Körper als feministischer Fetisch: Konsequenzen aus der Ausblendung des deutschen Kolonialismus.” W Weiß, Weißsein, Whiteness: Critical Studies on Gender an Racism, red. Martina Tissberger, Gabriele Dietze, Daniela Hrzán i Jana HusssmanKastein. Frankfurt/Main: Peter Lang.

Macpherson, C. B. 1962. Political Theory of Possessive Individualism: Hobbes to Locke. Oxford: Oxford University Press.

Marks, Karol. 1966. Przyczynek do krytyki ekonomii politycznej. W Karol Marks i Fryderyk Engels. Dzieta. T. 13. Warszawa: Książka i Prasa.

McRobbie, Angela. 2001. „»Everyone is Creative«: Artists as New Economy Pioneers?" http://www.opendemocracy.net/arts/article_652.jsp.

Mecheril, Paul. 2003. Prekäre Verhältnisse: Über natio-ethno-kulturelle Mehrfachzugehörigkeit. Münster: Waxmann.

Ott, Cornelia. 1997. „Lust, Geschlecht und Generativität: Zum Zusammenhang von gesellschaftlicher Organisation von Sexualität und Geschlechterhierarchie.” W Ein allägliches Spiel: Geschlechterkonstruktionen in der sozialen Praxis, red. Irene Dölling i Beate Krais. Frankfurt/Main: Suhrkamp.

Pieper, Marianne i Encarnación Gutiérrez Rodríguez (red). 2003. Gouvernementalität: Ein sozialwissenschaftliches Konzept im Anschluss 
an Foucault. Frankfurt/Main: Campus.

Panagiotidis, Efthimia. 2005. „DenkerInnenzelle X: Prekarisierung, Mobilität, Exodus." arranca! 32 (Summer).

Panagiotidis, Efthimia i Vassilis Tsianos. 2004. „Reflexive Prekarisierung: Eine Introspektion aus dem Alltag von Projektlinken." Fantômas 6 (Winter).

Pühl, Katharina. 2003. „Der Bericht der Hartz-Kommission und die »Unternehmerin ihrer selbst«: Geschlechterverhältnisse, Gouvernementalität und Neoliberalismus." W Gouvernementalität: Ein sozialwissenschaftliches Konzept im Anschluss an Foucault, red. Marianne Pieper i Encarnación Gutiérrez Rodríguez. Frankfurt/Main: Campus. Rambach, Anna i Marina Rambach. 2001. Les intellos précaires. Paris: Fayard.

Sarasin, Philipp. 2001. Reizbare Maschinen: Eine Geschichte des Körpers 1765-1914. Frankfurt/Main: Suhrkamp. 
Isabell Lorey - teoretyczka polityki związana z European Institute of Progressive Cultural Policies. Jej badania dotyczą teorii feministycznej i politycznej, biopolityki, politycznej immunizacji, prekaryzacji, władzy konstytuującej i zjawiska exodusu w ramach ruchów politycznych. Ostatnio opublikowała m.in. Figuren des Immunen: Elemente einer politischen Theorie (2011), Die Regierung der Prekären (2012).

\section{Dane adresowe:}

Isabell Lorey

European Institute of Progressive Cultural Policies

Gumpendorfer Straße 63b

1060 Vienna

e-mail: lorey@eipcp.net

\section{Cytowanie:}

I. Lorey, Urządzanie i samoprekaryzacja: O normalizacji wytwórców kultury, „Praktyka Teoretyczna” nr 4(14)/2014, http://www.praktykateoretyczna.pl/PT_nr14_2014_Polityki_ popkultury/05.Lorey.pdf (dostęp dzień miesiąc rok)

DOI: $10.14746 /$ prt.2014.4.5

Author: Isabell Lorey

Title: Governmentality and Self-Precarization: On the Normalization of Cultural Producers 